\title{
Bringing the other back home: the translation of (un)familiar hybridity
}

\author{
M. Rosario Martín Ruano \\ Universidad de Salamanca
}

\begin{abstract}
La vieja biblioteca en la que hemos vivido presenta hoy un paisaje en transformación. Entre las ruinas de lo que fue y lo que todavía no es, sólo hay lugar para las preguntas.

The old library in which we have lived so far presents a landscape in transformation. Amid the ruins of what was and still is not, there is room only for questions.

(Hugo Achugar)
\end{abstract}

Escribir es hacer preguntas.

To write is to pose questions.

(Sandra Cisneros)

Increasing migration and growing hybridation have fostered the emergence of new cross-cultural expressive forms that can hardly be considered in 'national' terms. The works written (mostly) in English by authors of Hispanic origin seem instead to inhabit the intercultural space of translation. The question is whether the translations (as usually conceived) of these works remain in an intercultural space. This article will examine the versions into Spanish of some of these hybrid works in order to determine how this (un)familiar Other is brought home: whether Otherness, difference and hybridity are maintained or neutralized. At least two models can be hinted at: one in which translation seems to return at the service of a 'national' literature; one which explores the possibilities of translation as an openly multicultural and multilingual space.

\section{Hybrid literature as translation}

The preceding diagnosis by the Uruguayan critic Hugo Achugar is incontrovertibly accurate. In recent times, traditional forms of literary expression have witnessed a profound and radical change, to a large extent linked to the transformations underway in the composition of current societies. In effect, improved access to other languages and cultures, together with increasing migration and growing hybridation, have fostered the emergence of new multicultural, multilingual forms of expression that are themselves a metonymic representation of new social configurations characterized by interculturality, creolism and métissage. These expressive forms seem to embody those texts of pleasure in which, according to Roland Barthes, different languages cohabit and coexist. In effect, as in Zadie Smith's White 
Teeth, a new type of literature is inhabited by "Babelians of every conceivable class and colour speaking in tongues" (Smith 2000: 292). As is also the case in Christine Brooke-Rose's Between, a novel staged by a conference interpreter in which more than ten languages joyfully merge and collide, or in Antonio Muñoz Molina's Carlota Fainberg, in which a Spanish academic migrated to the USA narrates his plight in a Spanglish as spontaneous as erudite, our time bears witness to the emergence of literary works which are located in the polylingual space characteristic of migrants, exiles and travellers, perhaps the very human condition of our post-Babelian era (Eoyang qtd. in Chan 2002: 49-50). In a way, these texts come to terms with the truth that, according to George Steiner, the prevailing monoglottal, monocultural conscience does not acknowledge, i.e., that it may well be the case that multilingualism and multiculturalism are not the historical and cultural exception but the norm (1998: 107); they seem to confirm what Mary Louise Pratt has suggested: that 'normal' communication might perhaps not follow the principles taken for granted by modern linguistics, which projects a clear-cut division between the different languages and idioms, and may instead generally develop within what she labels contact zones, "social spaces where disparate cultures meet, clash, and grapple with each other, often in highly asymmetrical relations of domination and subordination" (Pratt 1992: 4).

In any event, 'natural' as on these grounds it may seem to many, this new type of literature is seen as extremely defiant and subversive. "To write is to pose questions", says Sandra Cisneros in the second of our opening quotes, a statement that could be paraphrased as "to write is to call things, the status quo, the established order into question". In effect, works like those by Cisneros are transgressive as they jeopardize the hitherto sacrosanct principle of "national literatures', i.e., "the candid idea according to which literary traditions coincide and can coincide only with linguistic traditions and that all linguistic traditions would coincide with the principle of nations", in José Lambert's words (1995: 98); as they destabilize, to use Mary Snell-Hornby's enlightening formula (1997: 285), that "illusory equation "one nation : one culture: one language"" which is so dear to the Western world. For, as Choudhuri rightly perceives (1997: 25), it is characteristic of developed countries to maintain the illusion and to pursue the developmental dream of monolingualism. Thus, multilingual, multicultural texts are subversive inasmuch as they resist and combat the centripetal forces that established societies exert to consolidate a "normative grammar" (Gramsci), or that "unitary language" (Bahktin) aiming to tame heteroglossia; they are transgressive to the extent that they oppose monolingual complacency and disrupt the myth of the singularity, separateness of cultures.

In fact, because of the plurality of cultural codes and languages they embed, these texts can hardly be ascribed to a particular culture. Rather, they are unhomely fictions, deterritorialized and deterritorializing narratives: deterritorialized as they emerge in the frontier, from that Borderlands which lies amidst various cultures but belongs to none of them; deterritorializing because they challenge our acquired instinct to mapping - if we realize that 
the map is not the world, but the cartographer's representation of it, the challenge is, Dora Sales suggests (2001-2: 125), simply to read the world beneath our feet. This reading, however, is never linear, univocal, straight. These works cannot be traced back to a fixed origin or be anchored to a stable location. They remain suspended in a fluid third space, awaiting an adventurous reader willing to dive into such uneasy in-betweenness. These texts occupy, and bring the reader into, the nomadic space of translation.

Translation has recurrently served as a metaphor to describe the experience of displaced, hyphenated subjectivities, of those "restless hybrids" (Papastergiadis 1995) who, like the protagonist of Shame, by Salman Rushdie, see themselves as translated, as borne across. Likewise, the (trans)cultural textualities they produce are, in essence, translation: they draw on and cross over more than one culture, more than one language, more than one world experience. Precisely for this reason, translation has also been used to conceptualize the process of meaning construction this hybrid production triggers and ultimately requires. In these cases where cultures and languages fuse and compete, Samia Mehrez suggests (1992: 122, 137), translation becomes an integral part of the reading experience; moreover, this author says, we are to understand the importance of becoming perpetual translators in our reading of a multilingual world. Translation emerges as the mental process of becoming aware of cultural differences, and thus as a locus of resistance against the prevailing tendency towards homogenizing and neutralizing diversity into standardized codes. In other words, translation epitomizes the modality of critical, contrapuntal, ethical attitude which interculturality as a reality and as a goal requires. What remains to be determined is whether translation as a practice lives up to the expectations it creates as a metaphor; whether existing translations foster or neutralize cultural difference; and, more specifically, in the case of literature which emerges from the frontier and inhabits an intercultural, multilingual sphere, whether translations remain in, or recreate, a deterritorialized "third space" (Bhabha) or rather effect a reterritorialization, falling prey to, and collaborating with, the monolingual, monocultural programmes still dominant in a world which, in spite of its growing diversity, idolizes unity, integrity, oneness.

\section{Translating translation(s)}

Obviously, multidimensional as it is, the issue of how multicultural, multilingual texts are translated would require, and certainly deserves, an indepth, extensive analysis. Chan's (2002) recent essay is path-breaking in this regard: it provides a taxonomy of different types of multilingual texts and in parallel traces the most common translation solutions. These include multilingual renderings mimicking the coexistence of codes in the original, versions processing the 'intrusive' language(s) selectively and merely retaining certain passages or expressions symbolically, and monolingual renderings which either totally erase the marks of third languages or at most replace 
multilingualism with a diverse, hybrid typography, in which case italics very frequently commemorates the former presence of codes fallen in the translation process. In fact, confirming the pessimistic conclusion Susan Sontag arrives at in an essay in which she recalls how the celebrated re-translation into English of Thomas Mann's The Magic Mountain transforms a crucial French passage bursting into the German text also into English - the conclusion that "[translation is about] differentness[;] a way of coping with, and ameliorating, and yes, denying difference" (2003: 339) -, the latter strategy is a constant in translating multilingualism. Furthermore, it would indeed seem to be the only one possible in the light of prevailing ideas which run unquestioned within the discipline. Chan (2002: 49) critizices in this regard "the limits of existing translation theories which are based on a bilingual, one-to-one model" and argues for new theoretical paradigms which may account for the profusion of tongues characteristic of our post-Babelian era. We totally agree with Chan, as well as with Shantha Ramakrishna's conviction that "[...] the bilingual and bicultural nature of translation studies calls for revisiting some of the accepted notions in the discipline. We need to relocate the theory and practice of translation within contexts hitherto unexplored" (1997: 21-2).

This article will examine in more detail how the linguistic and cultural multiplicity characteristic of hybrid, multicultural texts is dealt with in translation. Given space restrictions, we will focus on the translation of some bicultural texts in which the Other (the language and culture which underlies, mixes with and alters the major language selected for expression) coincides with the main language and culture of the potential readership of the translation. In particular, we will examine different translation solutions in the versions into (mostly) Spanish of some works by various Chicano/a, Cuban-American, Dominican, Puerto Rican authors, originally written (mostly) in English but traversed by a Hispanic substratum. This particular scenario problematizes the conventional terminology currently used by translation studies for describing attitudes and behaviour towards the Other, which some authors perceive in need of profound revision (Carbonell n.d.: 5). For is it not a contradiction to talk about an Other that is ultimately familiar? Moreover, what does foreignizing mean when this (un)familiar Other must be brought back home? Does the preservation of alterity as conventionally conceived not entail a domesticating or naturalizing effect? Still, how can domesticity (not) be domesticated? The examples we will consider reveal that usual categories like foreign/familiar, foreignizing/domesticating, exoticism/naturalization or Other/Self are relative, contingent concepts far more complex and less defined than the opposed poles of the dichotomy which in the current literature they seem to be, and therefore that translation studies needs to enlarge its vocabulary and vision, still bound to traditional binary translation models, in order to explain the workings of translation when it faces linguistically and culturally ambivalent, pluralized texts that deny the taken-for-granted distinctions between original and receiving language/culture, and between Other and Self. For, as Lopes (1998: vii), the 
Portuguese translator of some of William Boyd's Portugal-based novels, says, the Other is Us in our case: alterity in the original is identity in the translation.

\title{
2.1. Dominant trends: neutralizing vs. recreating bilingualism
}

Basically, two opposed translation models come to mind as regards these bilingual, bicultural texts by authors of Hispanic origin which are to be inscribed in the language and culture underlying and sometimes popping up to their English surface. In one model, language and cultural diversity are neutralized into a monolingual, homogeneous version clearly at the service of the receiving literary tradition, of merely one culture; in another interculturality and diglossia are maintained or recreated, thus exploring the possibilities of translation as an openly multicultural and multilingual space. Actually, these two extreme models seem to match the translation politics followed by two of the translators of Sandra Cisneros's hybrid production, which combines English with Spanish. The result, nevertheless, is not a smooth fusion, but a coexistence of languages in constant fluctuation, in tension, conflict and diglossia. In contrast to humanist polyglots speaking prestigious, apparently interchangeable languages, the post-colonial hybrids' experience of multilingualism is saturated with power differentials and hierarchies that impinge on the use of their languages and regulate codeswitching (Mehrez 1992: 120-1; Dicker 1996: 1-33; Mezei 1998: 235-6). Cisneros's dedication opening up Woman Hollering Creek and Other Stories ((1992) [1991]) perfectly reflects this split, conflict-ridden, dual linguistic identity:

\author{
For my mama, \\ Elvira Cordero Anguiano, \\ who gave me the fierce language. \\ Y para mi papá, \\ Alfredo Cisneros del Moral, \\ quien me dio el lenguaje de la ternura. \\ Estos cuentitos se los dedico \\ con todo mi corazón.
}

To the best of our knowledge, there are two versions into Spanish(?) of this work: the first one, by Enrique de Hériz, was published by Ediciones B, Barcelona, Spain; the second one, by a Mexican translator living in the United States, Liliana Valenzuela, came out in the 'Vintage Español' series of Vintage Books, a division of the American publisher Random House. The translation solutions for the dedication quoted above could not differ more:

Para mi mamá,

Elvira Cordero Anguiano,

que me dio el lenguaje feroz. 


\author{
Y para mi papá, \\ Alfredo Cisneros del Moral, \\ quien me dio el lenguaje de la ternura. \\ Estos cuentitos se los dedico \\ con todo mi corazón. \\ (Cisneros / de Hériz 1992) \\ For my mama, \\ Elvira Cordero Anguiano, \\ who gave me the fierce language. \\ Y para mi papá, \\ Alfredo Cisneros del Moral, \\ quien me dio el lenguaje de la ternura. \\ Estos cuentitos se los dedico \\ con todo mi corazón. \\ (Cisneros/Valenzuela 1996)
}

Even in this brief dedication it becomes obvious that Enrique de Hériz reacts to the centralizing whistle of the Bahktinian unitary language or, to use Venuti's terminology, of that major language which hews to standards, constants, homogeneity (1998: 136). His translation seems to validate the pessimistic conclusion that "[s]eule les koinés, les langues 'cultivées', peuvent s'entretraduire" which Antoine Berman (1985: 79) gathered in the light of the workings of the dominant translation model, which he described as culturally ethnocentric and philosophically Platonic (46). Indeed, both labels apply to this first translation: it can be seen as ethnocentric as it consolidates the established code in the receiving culture to the detriment of difference; as Platonic to the extent that it privileges ideas over words, meaning over the medium, the signified over the signifiers. In this regard, the concept of translation de Hériz seems to have in mind is the transference of the sense conveyed by language(s). Obviously, this instrumental vision of language neglects the dialectics between the codes involved in the original, as well as the capacity of language(s) as a shaper of personal and cultural identity, of a sense of a very different ilk: the sense of belonging. By renouncing to clue readers in about code-switching, Cisneros's work is reduced to its narrative dimension, to a clear and univocal message which prevents the target readership from grasping the emotional strain and the cultural schizophrenia characteristic of the hybrid condition.

Liliana Valenzuela's translation, in contrast, perceives that the 'message' of this work cannot be taken at face value, as multilingualism itself is part of the meaning and indeed has a meaning, a purpose: Cisneros herself acknowledges a pedagogical aim in her work (qtd. in Godayol 1996: 59). Valenzuela takes up the challenge to alert readers to multilingualism, to reconstruct in translation a hybrid linguistic identity. Translation thus departs from its conventional function of rendering a text into another language, of processing difference for another culture, and, by maintaining the coexistence of English and Spanish in the 'translated' dedication, inscribes itself in the liminal, plural space of the border. In any event, the translator perceives 
that the observer is now on the other side of the frontier, which explains the perspectival shift brought about by the inverted use of italics. Valenzuela's version thus effects a relocation that is in essence paradoxical, as, contrary to de Hériz's rendering, it refuses to march into established territories, into mapped, culturally predetermined positions. Valenzuela's work is in this regard disturbing and subversive; it matches that modality of minoritizing translating that, according to Venuti (1998: 139), releases heteroglossia, destabilizes the major language by cultivating linguistic multiplicity and polychrony and is distinguished by highly inventive practices - inevitably.

Indeed, Valenzuela's purpose cannot be achieved with recourse to a wholesale, automatic strategy. Valenzuela not only aims to relocate language multiplicity, but the dialectical tensions between the codes involved, a goal that can hardly be met by mere opposition or substitution, by acritical, oneto-one inversion. It is clear from her version that, for Valenzuela, translating code-switching does not equal merely switching the codes (transforming the Spanish into English and vice versa), but rethinking its dynamics and recreating them - a thoughtful process that allows us to consider this translation as a follower of the ethical, reflective approach Antoine Berman proposed, in opposition to the prevailing ethnocentric, Platonic model, in order to receive "l'Autre en tant qu'Autre" (1985: 89). This becomes evident in the translation of the author's statement of indebtedness, originally "Los acknowledgments", where the author publicly expresses her gratitude, among others, to her mother and her editor:

\section{Los Acknowledgments \\ $[\ldots]$ \\ Gracias to my mother, la smart cookie, my S\&L financial bailout more times than I'd like to admit. \\ $[\ldots]$ \\ Praise to la bien bien linda Julie Grau, my editor. Ay, Julie, believe me, I am eternally grateful for your unflagging cariño, patience, and sensitivity through the labor and delivery of this book. \\ (Cisneros, Woman Hollering Creek: ix-x)}

Valenzuela conveys the message mainly in Spanish, but, through a handful of traits and selective markers, reminds the reader of the fact that the fierce language is in contact and in struggle with the language of emotions, which in the new context created by translation is also the language which facilitates understanding. Her translation negotiates these relations:

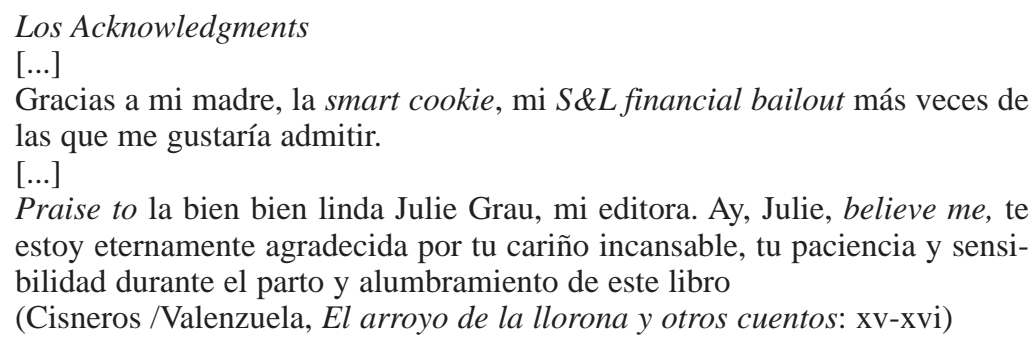


In contrast, Enrique de Hériz disregards heteroglossia in its multiple dimensions: conspicuously, English disappears without a trace, even from the contexts which Chicanos/as associate with the fierce language; nevertheless, the Spanish simultaneously loses emotional strength and evocative force. In fact, de Hériz's lexical selections and rhetorics are far more neutral and aseptic than Valenzuela's. For instance, as opposed to the gender-conscious version by the latter, de Hériz neglects the association of "labor" and "delivery" with childbirth and renders them with dispassionate words linked to mechanical processes, conjuring up no feelings, no emotions, no personal involvement:

\section{Los agradecimientos \\ [...]}

Gracias a mi madre, una chica despierta, mi fiadora financiera en más ocasiones de las que me gusta admitir.

[...]

Loa a la "bien bien linda" Julie Grau, mi editora. Ay, Julie, créeme, te estaré eternamente agradecida por tu incesante cariño, paciencia y sensibilidad a lo largo de la elaboración y entrega de este libro.

(Cisneros/de Hériz, Érase un hombre, érase una mujer: 9-10)

This is just another plane where the major language, devout of univocality and unequivocalness, of dictionary-based denotation, of depersonalized accuracy, gains ground to the detriment of the suggestive forms of minor languages that release what Venuti calls the remainder, a surplus of meaning and force generated by their marginal, non-standard status. In fact, de Hériz's and Valenzuela's versions do not only differ in their treatment of multilingualism; they exhibit a totally different position as regards language diversity at their disposal within Spanish. In this and other versions of Cisneros's works, de Hériz searches for the cultivated, prestigeful (written) language standard of Peninsular Spanish, in certain cases 'polishing up' the author's deliberately oral style; Valenzuela, on the contrary, introduces regionalisms, archaisms, non-standard terms and expressions, common but incorrect forms typical of spoken language, as well as traits of what is derogatorily called the pocho Spanish of Chicanos (Valenzuela 2003: 541). Even when remaining within the limits of Spanish, Valenzuela challenges the dominant discourse by exploiting its enormous variety and by bringing to the fore its marginal, peripheral forms. As she explains in her Translator's Note to Caramelo (2003: 543), Valenzuela openly commits herself to a subversive project, to the redefinition of the power relations in the target language. In her versions, translation embraces a semiotics of defiance and thus becomes a counterdiscourse.

Needless to say, subjective as any translation always is, the divergences found in the behaviour of these two translators cannot be attributed merely to personal preferences and individual decisions. Translations are always inscribed in particular contexts and are therefore influenced by the expectations prevailing in those contexts, and usually act as indicators of 
existing translation norms. Hériz's conservatism is to a good extent heir to the location of his translations, emanating from the very centre which has historically been the source of the Spanish language standard. In effect, de Hériz's translations are in line with the imperialist or even defensive attitude usually adopted at the service, or under the pressure, of a (purportedly) solid, self-reliant cultural identity which, be it out of blind self-congratulation or out of fear, in any event tends to neutralize difference and diversity (Robyns 1994). Hériz obeys and in turns feeds a centralism and strict linguistic purism that, far from being a historical exigency, still pervades in the Spanish editorial medium, arguably hampering the consolidation of more creative formulas which may deal with multilingualism and/or come to terms with language variety. In any event, although this centralism and linguistic purism might be aggravated in Spain, they are by no means exclusive of the Peninsula, as they are radiated to the Spanish-speaking areas that are still under its symbolic influence or under its real dominance - let us not forget that Spanish publishers to a large extent control the Latin American market. Multiple details attest to the persistence of extremely vigorous centripetal forces decisively influencing translation's response vis-à-vis language multiplicity and language diversity. Restricting ourselves to the cultural scenario within the scope of this article, it is not accidental that monolingualism is the most frequent translation strategy used for translating these bilingual texts, as, apart from de Hériz's versions, is borne out by Costa Picazo's rendering of In The Time of the Butterflies (Álvarez 2003 [1994]), Marisol Palés's version of Dreaming in Cuban (García 1993) or Rosario Ferré's self-translated The House of The Lagoon (1998 [1995]) or Eccentric Neighborhoods (1999a, 1999b). Contravening the hybrid condition of the original texts, and contravening its own intercultural nature, translation acts in these cases as a mechanism of (mono)cultural reproduction. Most paradoxically, given the essentially translated nature of the original texts, translation happens to inhibit translatedness. Exiles are repatriated, but provided they keep their migrant experience quiet. In a culture which worships homogeneity, this (un)familiar hybridity must be purified of its strangeness. In order to be brought back home, the Other has to be assimilated.

The centripetal impulse is also evident in the supremacy granted to a supposedly neutral Spanish language standard over the different varieties, which, for instance, becomes visible in the drive to quickly publish a second edition of the Spanish version of In the Time of the Butterflies purged of the typically Argentinian words and expressions appearing in the first Buenos Aires-based edition (cf. Valerio-Holguín n.d.). Perhaps because, as Godard suggests (1997: 158), the ruling social formation strives to make multiaccentuality uniaccentual, translation disregards minoritarian varieties, and does not perceive difference as enriching but as limiting its potential scope. In fact, translation, a culturally underestimated practice in need of legitimation, usually seeks out the prestigeful norm in order to secure its acceptance. Maybe this explains why these hybrid narratives mostly located in (Latin)American settings are often translated into the modality of Spanish 
spoken in Spain, even at the risk of introducing serious inconsistency and problems at the level of cultural representation. In this regard, in relation to Jordi Gubern's version of Julia Álvarez's How the Garcia Girls Lost Their Accent (which on the other hand counteracts monolingualism by marking the words originally in Spanish with the use of italics, by retaining certain English expressions and by including cultural exegesis in translator's notes), Irizarry (n.d.) points out that this translation responds to the hegemonic centre of the old colonial power "which certainly still maintains its fantasies of transnational domination"; Cipria (2000), on her part, pointing out that this novel which unfolds in (or in relation with) the Dominican Republic systematically uses the pronoun vosotros (second person plural, exclusive of Castilian), seems to suggest that the hegemonic cultural group, by imposing its varieties as universal traits, shows no consideration for issues of identity which are central to these novels. The variety which has traditionally been elevated into the 'norm' stifles a value so cherished by these works, heterogeneity.

But surely this is not the only 'norm' restraining the search for innovative, non-conventional translation solutions for this new literature committed to multilingualism and language diversity. As a rule, experimentalism is at odds with linguistic traditionalism and with purist attitudes. And, according to Franco Aixelà (1996: 65-66), when it comes to translation, prescriptivism is exacerbated among Spanish publishers. It is not only that standards of correctness become stricter in proximity to the centre, as one can discover with a mere glimpse at the different editions of the Spanish version of Rosario Ferré's Eccentric Neighborhoods: the one published by Ediciones Destino, Barcelona, amends the author's orthographical slips, whereas these appear uncorrected in the Vintage Español Series. The degree of tolerance to any deviation from the tacitly prevailing standard also diminishes proportionally. Proof of this seems to be the decision taken by the Spanish distributor of Liliana Valenzuela's rendering of Cisneros's recent novel, Caramelo, to include an initial note warning the readers that they are about to read a non-standard variety. The perceived need to explicitly inform them that "[1]a presente edición reproduce la forma en que los habitantes de las comunidades fronterizas sintetizan un lenguaje formado de palabras en inglés y español, el llamado 'lenguaje de la frontera'" (Cisneros 2003: 6), playing safe in anticipation of possible surprise or disapproval on the part of the public, unmistakably hints at the prevailing expectations about and the normativeness of the use by default of standard, 'orthodox' language in translated versions. In fact, the Spanish editorial industry favours and requires a transparent and fluid model of translation, to a large extent based upon the observance of the traditional rules of standard Spanish. In general, this tacit normativity, and the acknowledgement of its limitations, explains recent calls for new models of translation for a new type of literature which, through métissage, precisely questions and destabilizes the notion of 'idiomatic' language use and other long-established norms and conventions (Sáenz 2000; Sales 2001-2). In particular, it may also explain the lack of dis- 
tribution in Spain of Esmeralda Santiago's self-translation of When I Was Puerto-Rican.

\subsection{New avenues: translating into the language of the frontier.}

Santiago's translation practice represents a third way in relation to multilingualism and language variety. Cuando era puertorriqueña fully confronts the new readership with the hybrid condition of the narrator's world, which is (re)articulated without abandoning the precarious but nevertheless singularly personal shelter of the border. Accordingly, the target language, although mostly Spanish, is essentially hybrid. In this version, both English and Spanish inhabit Negi's surrounding environment:

Yo entendía casi todas las palabras en los cuadritos que estábamos supuestas a llenar: Name, Address (City, State) y Occupation. Se la devolvimos a Mister Grant. (Santiago, Cuando era puertorriqueña: 245)

Moreover, both languages do not merely happen to live side by side; they coalesce to form the plural voice of the migrant, who internalizes and requires both, as can be seen in this spontaneous family conversation:

- Si lo cuentas ahora [un cuento] -ofreció Don Julio- te doy un dáim. [...]

- Okey. Había una vez, y dos son tres...

- Un momentito, que tengo que ir al baño. Don nobodi téik mai plais - nos advirtió Alicia. (254-5)

This passage also shows the transformative nature of hybridity, which becomes highlighted through the use of an interlanguage that results from the filtering of one language with another, a strategy also used by Valenzuela in her version of Caramelo: "Go hell... Guat's a matter... Seim tu yu moder!", for instance, are the blasphemous complaints of the Reyes brothers (Cisneros/ Valenzuela, Caramelo: 22). The radicality of Santiago's translation, nevertheless, lies in the fact that the inevitable distortion and contagion of the languages involved due to language contact is not limited to conversation transcriptions nor used sporadically. The idiom of the entire translation is radically métisse, (un)familiarly Other, domestic but strange: Spanish with an alien cadence, interfered as it is by English grammar, syntax and lexis; the Spanglish or "espanglés" which, as Santiago herself acknowledges in her Introduction to the Spanish version (1994: xvii), is currently her language, an idiom invented out of a need to express herself, to voice her hybrid identity.

Reading Santiago's version produces uncertainty: is it conscious resistance or just lack of competence? Subversion or merely attrition? And where is the one assessing positioned? True, from a normative point of view, this translation is certainly inaccurate, difficult to read and grammatically dubious. But which is the 'normative grammar' of the language of the bor- 
der? How can translation translate, and invite the reader to continue translating without essentializing, the essential translated nature of this Other that seems so (un)familiar, of the exile, the migrant subject? By "forc[ing] the readers to abandon the comfort of their expectations of normative discourse" (Irizarry n.d.) Santiago may be seen as "negotiating translational resistances" which may open up avenues for new translating practices on a par with our post-national world (Bachmann-Medick 1996). Santiago's main merit, like Cisneros's with her writing, is to pose questions by translating. For, as Hugo Achugar diagnoses in the initial quote of this paper, in this landscape in transformation, there is room only for questions. Sometimes questions are more valuable than answers.

\section{Bibliography}

\section{Primary texts}

Álvarez, Julia (2003 [1994]). En el tiempo de las mariposas. (tr. Rolando Costa Picazo). Madrid: Suma de Letras.

Álvarez, Julia (1994). De cómo las chicas García perdieron su acento. (tr. Jordi Gubern). Barcelona: Ediciones B.

Cisneros, Sandra (1992 [1991]). Woman Hollering Creek and Other Stories. New York: Vintage.

Cisneros, Sandra (1992). Érase un hombre, érase una mujer. (tr. Enrique de Hériz). Barcelona: Ediciones B.

Cisneros, Sandra (1996). El arroyo de la llorona y otros cuentos. (tr. Liliana Valenzuela). New York: Vintage Español.

Cisneros, Sandra (2003). Caramelo o Puro cuento. (tr. Liliana Valenzuela). Barcelona: Seix Barral.

Ferré, Rosario (1998 [1995]). La casa de la laguna. Barcelona: Emecé.

Ferré, Rosario (1999a). Vecindarios excéntricos. Barcelona: Destino.

Ferré, Rosario (1999b). Vecindarios excéntricos. New York: Vintage Español.

García, Cristina (1993). Soñar en cubano. (tr. Marisol Palés). Madrid: Espasa Calpe.

Santiago, Esmeralda (1994). Cuando era puertorriqueña. New York: Vintage Español.

Smith, Zadie (2000). White Teeth. London: Penguin.

\section{Secondary texts}

Álvarez, Roman \& África Vidal (eds) (1996). Translation, Power, Subversion, Clevedon/Philadelphia/Adelaida: Multilingual Matters.

Bachmann-Medick, Doris (1996). "Cultural Misunderstanding in Translation: Multicultural Coexistence and Multicultural Conceptions of World Literature." EESE 7. http://webdoc.sub.gwdg.de/edoc/ia/esse/artic96/bachmann/7_96.html (consulted 21.05.2003)

Berman, Antoine (1985). "La traduction et la lettre ou l'auberge du lointain." A. Berman et al. Les tours de Babel (Essais sur la traduction). Mauvezin: T.E.R., 35-150.

Carbonell, Ovidi (n.d.), “There Was, There Was Not: Newness, Exoticism, 
Translation And Our Need for Other Worlds.” http://www.soas.ac.uk/literatures/satranslations/Carbon.pdf (consulted 05.05.2003).

Chan, Leo Tak Hung (2002). "Translating Bilinguality. Theorizing Translation in the Post-Babelian Era." The Translator 8(1), 49-72.

Choudhuri, Indra Nath (1997). "Plurality of Languages and Literature in Translation: The Post-colonial Context." S. Ramakrishna (ed.) (1997). Translation and Multilingualism: Post-Colonial Contexts. Delhi: Pencraft International, 25-33.

Cipria, Alicia B. (2000). "Dealing with Linguistic and Cultural Identity in Literary Translation: Analysis of the Spanish translation of How the Garcia Girls Lost Their Accent by Julia Álvarez." Paper presented at the 2000 ATA Conference in Orlando, Florida.

Dicker, Susan (1996). Languages in America. A Pluralist View. Clevedon: Multilingual Matters.

Drescher, Horst W. (ed.) (1997). Transfer: Übersetzen-Dolmetschen-Interkulturalität. Frankfurt: Peter Lang

Franco Aixelá, Javier (1996). "Culture-specific Items in Translation.” R. Álvarez \& A. Vidal (eds) (1996). Translation, Power, Subversion, Clevedon/Philadelphia/Adelaida: Multilingual Matters, 52-78.

Godard, Barbara (1997). "Culture as Translation.” S. Ramakrishna (ed.) (1997). Translation and Multilingualism: Post-Colonial Contexts. Delhi: Pencraft International, 157-82.

Godayol, Pilar (1996). "Sandra Cisneros: living on the frontera." In Other Words 7, $55-61$.

Fernández, Gonzalo \& Manuel C. Feria (eds) (1995). Orientalismo, exotismo y traducción. Cuenca: Ediciones de la Universidad de Castilla-La Mancha.

Hyun, Theresa \& José Lambert (eds) (1995). Translation and Modernization. Tokyo: Tokyo University Press.

Irizarry, Guillermo (n.d.). "Travelling Textualities and Phantagmagoric Originals: A Reading of Translation in Three Recent Spanish-Caribbean Narratives." http://www.lehman.cuny.edu/ciberletras/-v04/Izarry.html (consulted 21.05.2003).

Lambert, José (1995). "Literatures, Translation and (De)Colonization.” T. Hyun \& J. Lambert (eds) (1995). Translation and Modernization. Tokyo: Tokyo University Press, 98-117.

Lopes, Maria Alexandra (1998). "Prefácio à Tradução: Identidade versus Alteridade ou Do Destino Precário do Tradutor." William Boyd. O Destino de Nathalie " $X$ ". Algés: Difel, i-viii.

Mehrez, Samia (1992). "Translation and the Postcolonial Experience: The Francophone North African Text." L.Venuti (ed.) (1992). Rethinking Translation: Discourse, Subjectivity, Ideology. London/New York: Routledge, 120-38.

Mezei, Kathy (1998). "Bilingualism and Translation in/of Michèle Lalonde's Speak White." L. Venuti (ed.) (1998). Translation \& Minority. Manchester: St Jerome. Special issue of The Translator 4 (2), 229-48.

Papastergiadis, Nikos (1995). "Restless Hybrids." Third Text 32, 9-18.

Pratt, Mary Louise (1992). Imperial Eyes: Travel Writing and Transculturation. London/New York: Routledge.

Ramakrishna, Shantha (ed.) (1997). Translation and Multilingualism: Post-Colonial Contexts. Delhi: Pencraft International.

Robyns, Clem (1994). “Translation and Discursive Identity.” Poetics Today 15(3), 404-28. 
Sáenz, Miguel (2000). "La traducción de una nueva literatura." Gonzalo Fernández \& Manuel C. Feria (eds). Orientalismo, exotismo y traducción. Cuenca: Ediciones de la Universidad de Castilla-La Mancha, 175-8.

Sales, Dora (2001-2). "Reflexiones en torno a la supervivencia transcultural: leer el mundo bajo nuestros pies." Debats 75, 115-26.

Snell-Hornby, Mary (1997). "How many Englishes? Lingua Franca and Cultural Identity as a Problem in Translator Training." H. W. Drescher (ed.) (1997). Transfer: Übersetzen-Dolmetschen-Interkulturalität. Frankfurt: Peter Lang, 279-90.

Sontag, Susan (2003). “On Being Translated.” Where The Stress Falls. London/New York: Vintage, 334-47.

Steiner, George (1998). Errata. El examen de una vida. (tr. Catalina Martínez). Barcelona: Siruela.

Valenzuela, Liliana (2003). "Nota a la traducción: el revés del bordado." S. Cisneros (2003). Caramelo o Puro cuento. Barcelona: Seix Barral, 539-44.

Valerio-Holguín, Fernando (n.d.). "En el tiempo de las mariposas de Julia Álvarez: Una reinterpretación de la Historia." Colorado State University. http://lamar.colorstate.edu/ favalerio/juliaalvarez.htm (consulted 05.05.2003).

Venuti, Lawrence (ed.) (1992). Rethinking Translation: Discourse, Subjectivity, Ideology. London/New York: Routledge.

Venuti, Lawrence (ed.) (1998). Translation \& Minority. Special issue of The Translator 4 (2). Manchester: St Jerome. 